ISSN 2073-4441

www.mdpi.com/journal/water

Review

\title{
Dye Waste Treatment
}

\section{Siew-Teng Ong ${ }^{1}{ }^{*}$, Pei-Sin Keng ${ }^{2}$, Weng-Nam Lee ${ }^{3}$, Sie-Tiong $\mathrm{Ha}^{1}$ and Yung-Tse Hung ${ }^{4}$}

1 Department of Chemical Science, Faculty of Science, Universitit Tunku Abdul Rahman, Jalan Universiti, Bandar Barat, 31900 Kampar, Perak, Malaysia; E-Mail: hast_utar@yahoo.com

2 Department of Pharmaceutical Chemistry, International Medical University, No.126 Jalan 19/155B, Bukit Jalil, 57000 Kuala Lumpur, Malaysia; E-Mail: pskeng@yahoo.com

3 Department of Science, Faculty of Engineering and Science, Universiti Tunku Abdul Rahman Jalan Genting Kelang, Setapak 53300 Kuala Lumpur, Malaysia; E-Mail: elvislee_1122@yahoo.com

4 Department of Civil and Environmental Engineering, Cleveland State University, Cleveland, OH 44115, USA; E-Mail: yungtsehung@yahoo.com

* Author to whom correspondence should be addressed; E-Mail: ongst_utar@yahoo.com; Tel.: +605-4688888; Fax: +605-4661676.

Received: 5 January 2011; in revised form: 24 January 2011 / Accepted: 25 January 2011 / Published: 16 February 2011

\begin{abstract}
Dye wastes represent one of the most problematic groups of pollutants because they can be easily identified by the human eye and are not easily biodegradable. This literature review paper highlights and provides an overview of dye waste treatments performed over the three years period from 2008-2010. Noteworthy processes for the treatment of dye waste include biological treatment, catalytic oxidation, filtration, sorption process and combination treatments.
\end{abstract}

Keywords: dyes waste; textile effluents; treatment methods; modeling

\section{Biological Treatment}

The co-removal of chromate $\mathrm{Cr}(\mathrm{VI})$ and azo dye Acid Orange 7 (AO7) using Brevibacterium casei under nutrient-limiting conditions has been studied [1]. AO7 was used as an electron donor by the reduction enzyme of Brevibacterium casei for the reduction of $\mathrm{Cr}(\mathrm{VI})$. The reduced chromate, $\mathrm{Cr}(\mathrm{III})$, complexed with the oxidized AO7 formed a purple intermediate. By using response surface 
methodology, the optimal conditions for chromate reduction and dye decolorization were found to be $0.24 \mathrm{~g} / \mathrm{L}$ glucose, $3.0 \mathrm{~g} / \mathrm{L}\left(\mathrm{NH}_{4}\right)_{2} \mathrm{SO}_{4}$ and $0.2 \mathrm{~g} / \mathrm{L}$ peptone at $\mathrm{pH} 7$ and $35^{\circ} \mathrm{C}$. Ghasemi and colleagues (2010) studied the decolorization of different azo dyes by Phanerochaete chrysosporium RP 78 under optimized conditions [2]. Experimental results showed that the decolorization of azo dyes was due to an enzymatic degradation and $100 \%$ decolorization was achieved after 24 hours of reaction.

The possibility to decolorize Direct Red-80 and Mordant Blue-9 individually and in a mixture using immobilized Phanerochaete chrysosporium in a batch-operated rotating biological contactor (RBC) reactor was performed [3]. Experimental results showed that the decolorization efficiencies were in the range of $94-100 \%$ and $77-97 \%$ for individual and a mixture of dyes, respectively. A fungal isolate Aspergillus terreus SA3 from wastewater of the textile industry was utilized for the removal of dye Sulfur Black in a stirred tank bioreactor [4]. The color removal efficiency in the stirred tank reactor system was $84.53 \%$ with $50 \mathrm{mg} / \mathrm{L}$ initial dye concentration.

Meanwhile, the potential of Lemna minor (L.) for the treatment of reactive dye polluted wastewater was investigated [5]. Results showed that 59.6\% maximum dye removal was found in samples containing $2.5 \mathrm{mg} / \mathrm{L}$ initial Brilliant Blue and $1 \mathrm{mg} / \mathrm{L}$ of triacontanol. Karacakaya and colleagues (2009) investigated the removal capabilities of Synechocystis sp. and Phormidium sp. for reactive dyes such as Reactive Red, Remazol Blue and Reactive Black B [6]. Their results showed that the removal efficiencies of these cyanobacteria were higher in media containing triacontanol hormone.

In the biosorption study of acid dyes by brown alga, the reaction was found to be spontaneous and exothermic for both Acid Blue 324 (AB 324) and Acid Red (AR 337) [7]. The equilibrium data fitted well to both Langmuir and Freundlich isotherms with maximum adsorption capacity $224 \mathrm{mg} / \mathrm{g}$ and $323 \mathrm{mg} / \mathrm{g}$ for AB 324 and AR 337, respectively. The capability of narrow-leaved cattails, a species of wetland plant to remove synthetic reactive dye wastewater was attempted and the experimental results suggested that the decolorization of reactive dye wastewater by this plant was as effective as $60 \%$ [8].

In the same year, a study on dye degradation by Aspergillus niger was conducted [9]. Experimental results revealed that a complete color removal of Turquoise Blue and Red ME4 BL was achieved. The effect of introducing poly(amic acid) onto the surface of Corynebacterium glutamicum showed that with the increased density of carboxyl groups on the surface of biomass, the uptake of Basic Blue was greatly affected due to the greater electrostatic attraction forces that occurred [10].

Results from a study on isolation of bacteria indicated that six isolates showed maximum percent decolorization of four commonly used textile dyes-Red HE8B, Orange TCL, Green B and Black BT [11]. Different carbon and nitrogen sources, $\mathrm{pH}$, and temperature also affected the decolorization efficiency. Enterococcus gallinarum strain was isolated from the effluent treatment plant of a textile industry and was used for the decolorization of Direct Black 38 (DB 38) [12]. Kinetic study of DB38 decolorization was found to be higher in Luria Broth $(12.8 \mathrm{mg} / \mathrm{L} \mathrm{h}$ and $490.6 \mathrm{mg} / \mathrm{L})$ than in minimal medium $(4.09 \mathrm{mg} / \mathrm{L} \mathrm{h}$ and $161.84 \mathrm{mg} / \mathrm{L})$. At the same time, the decolorization ability of acclimatized textile sludge was performed [13]. In this study, a continuous culture experiment showed that the acclimatized sludge could decolorize $76 \%$ of $100 \mathrm{mg} / \mathrm{L}$ of DB 38 .

Treatment of colored effluents with lignin-degrading enzymes was carried out [14]. This study reported that terrestrial white-rot basidiomycetous fungi and their lignin-degrading enzymes laccase, manganese-peroxidase and lignin peroxidases were efficient in the treatment of colored effluent. Meanwhile, sulfate-reducing bacteria (SRB) that grew on modified Postgate C medium (PC) 
containing chromium (VI) were isolated from industrial wastewater for the treatment of Remazol Blue, Reactive Black B, and Reactive Red RB [15]. Results revealed that 25 to $30 \%$ of initial dye concentration was removed from the medium at the end of a 72-h incubation period.

The salinity effects in the decolorization of azo dye by Shewanella $s p$. were tested and the results showed that under static and low oxygen conditions, and a salt concentration of $60 \mathrm{~g} \mathrm{NaCl} / \mathrm{L}$, the bacterium decolorized $100 \mathrm{mg}$ dye/L [16]. The addition of glucose or $\mathrm{NH}_{4} \mathrm{NO}_{3}$ inhibited the decolorization process, whereas yeast extract and $\mathrm{Ca}\left(\mathrm{H}_{2} \mathrm{PO}_{4}\right)_{2} \cdot \mathrm{H}_{2} \mathrm{O}$ enhanced the decolorization rate. On the other hand, $100 \%$ degradation of dye Brown 3REL by Bacillus sp. VUS was achieved within eight hours at static anoxic condition [17]. This bacterium was also able to degrade $80 \%$ of dye in textile effluent.

\section{Catalytic Oxidation}

The results of heterogeneous catalytic ozonation of Methylene Blue using volcanic sand showed that this method yielded a higher removal efficiency of Methylene Blue compared to a homogenous system [18]. The results obtained also implied the importance of chemical surface properties in Methylene Blue oxidation reactions, which suggested that the acid surface sites of volcanic sand play a key role in the reaction.

The study of the photocatalytic efficiencies of the composite catalyst nano- $\mathrm{Cu}_{2} \mathrm{O} / \mathrm{TiO}_{2}$ prepared using electrokinetic system (EK) on the degradation of Methylene Blue showed that the decomposition of the dye increased with increasing EK preparation time [19]. It was also found that the loading of $\mathrm{Cu}_{2} \mathrm{O}$ on the $\mathrm{TiO}_{2}$ surface could greatly enhance the photocatalytic effect of the catalyst.

The efficiency of $\mathrm{TiO}_{2}$ in removing dye waste was further supported in a study using Basic Blue 3 as the targeted pollutant [20]. In this study, optimization of photocatalytic degradation of Basic Blue 3 under UV light and $\mathrm{TiO}_{2}$ nanoparticles in a photoreactor was investigated. Central composite design (CCD) was used for optimization and results showed that maximum decolorization was achieved at an initial dye concentration of $10 \mathrm{mg} / \mathrm{L}$, flow rate $100 \mathrm{~mL} / \mathrm{min}$ and reaction time of 120 minutes. In another study involving the self cleaning and photocatalytic properties of $\mathrm{TiO}_{2}$ entrapped PVDF ( $\left.\mathrm{PVDF} / \mathrm{TiO}_{2}\right)$ membrane, the results indicated that the removal rate of Reactive Black 5 under UV light was faster as compared to the rate of aromatic ring structure [21].

The applicability of composite nanofibers of poly(vinyl alcohol)/poly(N,N-dimethylaminopropyl acrylamide) hydrogel and $\mathrm{TiO}_{2}$ for a novel treatment of acidic wastewater was attempted [22]. High efficiency of photocatalytic decomposition of dye was obtained by the fast swelling of hydrogel in acidic conditions and the uniform dispersion of $\mathrm{TiO}_{2}$ by sonication. The investigation of the $\mathrm{TiO}_{2} / \mathrm{Ag}$ photocatalysis system for decolorizing Procion Red MX-5B indicated that the Ag carrier from the $\mathrm{TiO}_{2} / \mathrm{Ag}$ catalyst has the oxidizing ability to degrade MX-5B color even in the absent of UV-A, however $\mathrm{TiO}_{2}$ alone was ineffective [23].

As an alternative to using $\mathrm{TiO}_{2}$, the possibility of using a new photo-catalyst of silver nanoparticles attached on the surface of amidoxime fibers to degrade Methyl Orange (MO) under sunlight was attempted [24]. Results obtained indicated that the silver nanoparticles initiated and mediated the photo-oxidation reaction of MO through localized surface plasmon resonance under sunlight. The preparation and photocatalytic properties of a novel dumbbell shaped $\mathrm{ZnO}$ microcrystal photocatalyst 
was studied [25]. The $\mathrm{ZnO}$ photocatalyst has a unique dumbbell shape and it was used to degrade Crystal Violet, Methyl Violet and Methylene Blue with degradation efficiencies of $68.0 \%, 99.0 \%$ and $98.5 \%$, respectively.

Catalytic oxidation of simulated wastewater containing Acid Chrome Blue $\mathrm{K}$ using chlorine dioxide as oxidant was investigated [26]. The activated carbon- $\mathrm{MnO}_{2}$ catalyst was used for this catalytic oxidation and the removal efficiency of Acid Chrome Blue K was $87.8 \%$.

For electrochemical oxidation removal of dye wastewater, the degradation of Remazol RB 133 was achieved with the aid of photovoltaic (PV) cells to power an electrochemical filter press reactor [27]. Different degradation rates were obtained by using different PV arrays and electrochemical configurations. The effect of an indirect electrochemical oxidation method for the decolorization of textile wastewater was explored [28]. Graphite and sodium chloride were used as electrode and electrolyte, respectively. Various influential variables that govern the efficiency of the decolorization and degradation process of Reactive Yellow 3 (RY3) were studied. Kinetic analysis indicated that the electrochemical decolorization rates might follow a first order model.

Numerous studies have also been reported investigating the usefulness of hydrogen peroxide, $\mathrm{H}_{2} \mathrm{O}_{2}$, in assisting the removal of dyestuffs. The direct photocatalytic degradation of Rhodamine $\mathrm{B}$ (RB) by using thiocyanate complex of iron and $\mathrm{H}_{2} \mathrm{O}_{2}$ showed that the experimental results fitted well to pseudo-first-order kinetics [29].

The removal of reactive dye, BES Golden Yellow by using $\mathrm{H}_{2} \mathrm{O}_{2}$-assisted photolysis was studied [30]. Results indicated that UV irradiation and $\mathrm{H}_{2} \mathrm{O}_{2}$ addition are conditions needed for high removal efficiency of the dye. The potential of the $\mathrm{H}_{2} \mathrm{O}_{2} / \mathrm{UV}$ process for the removal of color before biological treatment indicated that the optimum conditions for the removal of color by up to $70 \%$ were

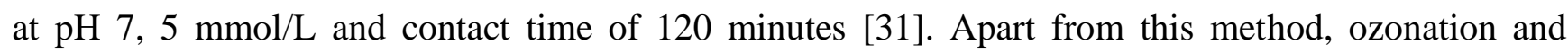
$\mathrm{H}_{2} \mathrm{O}_{2} / \mathrm{O}_{3}$ process can also be used as an effective method for cleaning textile effluent [32]. This method is mainly used for reactive, acid and direct dye treatment and less information is available for basic, dispersed and metal-complex dyes.

Wastewater treatment using ultrasound (US) was investigated [33]. The pollutants to be removed were reactive azo dyes, phenol and trichloroethylene. The cost of wastewater treatment for reactive azo dyes was in the range of $\$ 65$ per 1,000 gallon for US $+\mathrm{UV}+\mathrm{H}_{2} \mathrm{O}_{2}$ to $\$ 14,203$ per gallon for US alone. Similar techniques were studied on the degradation of C.I. Acid Orange by ultrasound enhanced heterogeneous Fenton-like process [34]. Experimental results obtained showed that the decolorization rate increased with ultrasonic power density, goethite addition and $\mathrm{H}_{2} \mathrm{O}_{2}$ concentration. In another experiment on the degradation of dye wastewater by use of an ultrasound/Fenton/nanoscale iron oxidation process, the Taguchi statistical method was employed to find the optimum experimental conditions. The percent removal of dye under optimal conditions was $99.91 \%$ [35].

The enhanced sonocatalytic degradation of azo dyes by $\mathrm{Au} / \mathrm{TiO}_{2}$ was investigated [36]. Results showed that the catalyst $\left(\mathrm{Au} / \mathrm{TiO}_{2}\right)$ with low Au loading $0.5 \mathrm{wt} \%$ and under common and commercial frequency $(40 \mathrm{kHz})$ ultrasonic irradiation has both accelerated discoloration and total organic carbon (TOC) removal of azo dyes such as Orange II, Ethyl Orange and Acid Red G as compared to bare $\mathrm{TiO}_{2}$ and nano-Au catalyst. At the same time, results from sonocatalytic degradation of Acid Red B and Rhodamine $\mathrm{B}$ by nano-sized $\mathrm{ZnO}$ powder under ultrasonic irradiation implied that the degradation ratios of Acid Red B and Rhodamine B in the presence of nano-sized $\mathrm{ZnO}$ powder were higher than 
those with only ultrasonic irradiation [37]. The kinetics of sonocatalytic reaction of both Acid Red B and Rhodamine B followed the pseudo-first-order model.

The degradation of MO solution by using microwave-assisted catalysis of $\mathrm{H}_{2} \mathrm{O}_{2}$ with chromium residue was studied [38]. Experimental results showed that some transition metal ions might take as catalysis for the degradation of MO. Chromium ion residue and $\mathrm{H}_{2} \mathrm{O}_{2}$ can form Fenton-like reagent and microwave heating can enhance the rate of degradation and utilization efficiency of $\mathrm{H}_{2} \mathrm{O}_{2}$ in the catalysis process.

For other catalytic oxidation processes, the percentage removal of various reactive dyestuffs was relatively high especially Reactive Black 5 (above 86\%) by using commercial laccase, which is a catalytic enzyme [39]. Enhanced dye wastewater degradation efficiency using a flowing aqueous film photoelectrocatalytic (PEC) reactor was studied [40]. Results proved that high treatment efficiency can be achieved for the degradation of Reactive Brilliant Blue X-BR by flowing aqueous film PEC process.

\section{Membrane Filtration}

Novel aromatic polyamide asymmetric nanofiltration membrane has been used for the treatment of dye aqueous solutions [41]. The nanofiltration membrane was prepared using a phase inversion method. The effects of various parameters such as $\mathrm{pH}$ and feed temperature were evaluated and the results showed that the rejection of acid, direct and reactive dyes were all above 95\%. The copoly(phthalazinone biphenyl ether sulfone) (PPBES) ultrafiltration (UF) membrane with low molecular weight cut-off possesses excellent thermal resistance which is suitable to be used in dye wastewater treatment at high temperature [42]. It showed 100\% rejection for Congo Red, Sulfur Black $\mathrm{B}$ and Gentian Violet.

A zero effluent process by using a membrane type solute separation system for a wet process house was studied [43]. In this study, reactive and disperse dyes were used for the dyeing process and the textile wastewater, which contains sizes, thickeners, pigments and soaps, was passed through ultrafiltration, nanofiltration and reverse osmosis membranes. Experimental results showed that only a small fraction of about $15 \pm 3 \%$ resulting from membrane filtration was not reusable and was unsuitable for processing.

Wastewater generated by a textile factory during dyeing of cotton with reactive dyes was treated using membrane filtration [44]. Three membranes were used in this study, one membrane for nanofiltration (NF) and two membranes for reverse osmosis (RO). The value of $\mathrm{pH}, \mathrm{COD}$, conductivity and coloration in terms of SAC were determined before and after filtration. Results revealed that the treated wastewater can be reused in the dyeing process.

\section{Sorption Process}

The adsorption properties of novel biocompatible composite (chitosan-zinc oxide nanoparticle) for both Direct Blue 78 and Acid Black 26 was investigated [45]. It was found that the chitosan-zinc oxide nanoparticles can be a suitable low-cost and eco-friendly adsorbent for the removal of dyes from aqueous solution. A study on the ability of chitosan to act as an adsorbent produced from waste seafood shells for the removal of five acid dyes, namely, Acid Green 25, Acid Orange 10, Acid Orange 
12, Acid Red 18, and Acid Red 73, was performed [46]. Experimental data was tested with three kinetic models and it was best correlated by the Elovich model. The utility of cross-linked quaternary chitosan as adsorbent for the removal of Reactive Orange 16 from aqueous solutions showed that the adsorption process was independent of $\mathrm{pH}$, well represented by Langmuir isotherm and a pseudosecond-order kinetic model [47]. It was found that the maximum adsorption capacity was 1,060 mg/g.

Batch adsorption technique was employed in the study of Methyl Orange onto calcined Lapindo volcanic mud [48]. The experimental results fitted well to Langmuir isotherm with a maximum adsorption capacity of $333.3 \mathrm{mg} / \mathrm{g}$. The thermodynamic parameters revealed that the reaction is spontaneous and endothermic. The adsorption study using mesoporous $\mathrm{TiO}_{2}$, which was prepared by hydrothermal method, showed that the maximum adsorption capacity for Methyl Orange and $\mathrm{Cr}(\mathrm{VI})$ were 454.5 and $33.9 \mathrm{mg} / \mathrm{g}$, respectively [49]. In this method, cetyltrimethylammonium bromide (CTAB) was used as a structure-directing agent. Results from transmission electron micrography (TEM) and nitrogen adsorption-desorption studies showed that mesoporous $\mathrm{TiO}_{2}$ has an average pore size of $5.2 \mathrm{~nm}$ and surface area of $161.2 \mathrm{~m}^{2} / \mathrm{g}$.

The removal of Methyl Orange from aqueous solution using metal-organic frameworks (MOF) materials based on chromium-benzenedicarboxylates (Cr-BDC) was carried out [50]. Two typical highly porous MOF materials, MIL-101 and MIL-53, were used for the removal of Methyl Orange. It was found that the adsorption capacity and kinetic constant of MIL-101 were greater than MIL-53 due to its high porosity and pore size as a result of modification.

Active manganese oxide was used for the treatment of wastewater containing Congo Red [51]. The removal of Congo Red by active manganese oxide was a reversible adsorption process. From the results obtained, the equilibrium data was well represented by Langmuir and Freundlich isotherms as well as a pseudo-second-order kinetic model. The experiment on the removal and recovery of Malachite Green dye from aqueous solution using environmentally stable adsorbent of tetrahedral silica and non-tetrahedral alumina was attempted [52]. Fourier transform-infrared spectroscopy (FTIR) was used to determine the tetrahedral framework of silica and non-tetrahedral framework of alumina. Thermodynamic studies showed that the adsorption process was endothermic and chemisorption.

The decontamination of dyeing wastewater by using tourmaline (non-metallic mineral) was investigated [53]. Experimental data showed that tourmaline acts selectivity on Acid Blue Black (10B) and the maximum adsorption of $1,000 \mathrm{~g}$ of tourmaline was $18 \mathrm{~g}$ of dye. Results also indicated that tourmaline decolorization is a combined action of chemical and physical adsorption.

A study on the porous magnetic microspheres prepared with sulfonated macroporous polydivinylbenzene as a template and their ability to remove cationic dyes was conducted [54]. Results indicated that Basic Fuchsin and Methyl Violet can be removed with high efficiency using porous magnetic microspheres which can be easily regenerated and repeatedly employed for wastewater treatment. The applicability of $\mathrm{Fe}_{3} \mathrm{O}_{4}$ hollow and magnetic nanospheres as an adsorbent for the removal of Neutral Red dye from aqueous solutions was tested [55]. The nanospheres were prepared by using a simple one-pot template-free hydrothermal method. Due to its nano-scale particle size, magnetic property and hollow porous material, it showed a favorable adsorption behavior for Neutral Red. 
The capability of various biosorbents such as fungi, bacteria algae, chitosan and peat in decolorizing dye wastewater was reviewed [56]. The effect of various factors on the decolorization of dye and pretreatment methods for enhancing biosorption capacity of the adsorbents were discussed. The potential of various low-cost adsorbents, such as agricultural waste, industrial solid waste, biomass clay minerals and zeolites for the removal of Methylene Blue has been reviewed [57]. Agricultural waste has been identified as one of the highly efficient low cost adsorbents for Methylene Blue as well as other dyes.

The removal of Reactive Red 23, Reactive Blue 171, Acid Black 1, and Acid Blue 193 from aqueous solution on fly ash was studied [58]. The experimental results showed that the removal of dyes on fly ash was $\mathrm{pH}$-dependent, higher initial dye concentration enhanced the adsorption capacity and the adsorption reaction was spontaneous and endothermic in nature. The usage of natural waste adsorbent-ash prepared by burning of brown coal in the heating station of Leskovac was employed in the adsorption of textile vat dye Ostanthren Blue GCD [59]. Various parameters such as $\mathrm{pH}$, initial dye concentration, Langmuir isotherm and kinetic models were used to evaluate the efficiency of the natural waste adsorbent-ash.

Chemically modified sugarcane bagasse as a potential low-cost biosorbent for dye removal was also studied [60]. The sugarcane bagasse was pretreated with phosphoric acid and used for the removal of Methyl Red from aqueous solution in a batch reactor at varying dye concentration, adsorbent dosage, $\mathrm{pH}$ and contact time. The adsorption efficiency of the modified sugarcane bagasse was in the order powdered activated carbon $>$ modified sugarcane bagasse $>$ natural sugarcane bagasse. The removal of basic dyes in single and binary dye systems were carried out using sugarcane bagasse [61]. The sorption process reached equilibrium at $60 \mathrm{mins}$, fitted well in the pseudo-second order kinetic model and Langmuir isotherm was applicable for all the dye systems studied.

The feasibility of using rice hull, an agricultural by-product, as a biosorbent for basic and reactive dye removal was explored [62]. With the introduction of different active sites through chemical modification, this enables rice hull to act as a potential low cost material for dye removal [62-64]. Column studies revealed that the breakthrough curves of the dyes being studied followed the typical $\mathrm{S}$ shape of packed-bed systems and it was bed-depth and influent-concentration dependent. Surface morphology analysis was also carried out using atomic force microscopy (AFM).

Other low-cost adsorbents, such as coconut and coffee husks were identified as potential biosorbents for hazardous dye Quinoline Yellow [65]. Results from batch experiment showed that the adsorption decreased with increasing temperature, which indicates that the reaction is exothermic. The experimental data fitted well in the pseudo-first-order kinetic model and the equilibrium data conform to both Langmuir and Freundlich isotherms. On the other hand, the potential of untreated coffee husks as a biosorbent for treatment of Methylene Blue contaminated waters was evaluated [66]. Both Langmuir and Freundlich models appeared to provide reasonable fittings for the experimental data. The study also revealed that the adsorption process is spontaneous and endothermic in nature.

The possibility of using grapefruit peel (GFP) as dye sorbent to remove Crystal Violet (CV) was conducted [67]. The adsorption of CV using GFP was tested under batch conditions. Results obtained were well described by the Langmuir isotherm with maximum adsorption capacity of $254.16 \mathrm{mg} / \mathrm{g}$. In the same year, another experiment was conducted under batch conditions on the biosorption of Acid Orange 52 onto leaf powder of Paulownia tomentosa Steud [68]. The equilibrium data obtained was 
well represented by Temkin and Langmuir isotherms with a maximum adsorption capacity of 10.5 $\mathrm{mg} / \mathrm{g}$ and the exothermic adsorption process followed the pseudo-second-order kinetic model. The biosorption of Congo Red by hydrogen peroxide, $\mathrm{H}_{2} \mathrm{O}_{2}$, to treat tendu waste under batch conditions was performed [69]. The tendu leaf was treated with $\mathrm{H}_{2} \mathrm{O}_{2}$ to produce an adsorbent with increased adsorption capacity. The maximum adsorption capacity of treated tendu waste was found to be $134.4 \mathrm{mg} / \mathrm{g}$.

The usage of agro-industrial wastes for the removal of basic dyes from aqueous solutions was discussed [70]. Experimental data showed that all the adsorbents used, which included coir pith, sawdust and sugarcane fiber, were effective for the removal of Crystal Violet and Rhodamine B and their adsorption capacities are comparable with other reported adsorbents. The removal of basic dyes from wastewater by adsorption was studied using waste ashes [71]. In this research, waste ash was obtained from coal combustion. The adsorption of basic dye Astrazon Green $\mathrm{M}$ was analyzed and results showed that it followed Langmuir isotherm and pseudo-second-order kinetic model.

Bottom ash and deoiled soya can also be used as adsorbents for the removal of Congo Red [72]. The removal efficiencies of bottom ash and deoiled soya were studied to determine the effect of $\mathrm{pH}$, dye concentration, amount of adsorbents, Langmuir and Freundlich isotherms. Column study depicted good adsorptive tendencies for Congo Red with $96.95 \%$ and $97.14 \%$ saturation on bottom ash and deoiled soya, respectively. The possibility of producing an adsorbent for dye removal by calcinating waste drilling fluids was explored [73]. The adsorption capacity of the adsorbent to five industrial dye solutions was equivalent to that of active carbon.

It is also worthy to mention the utilization of dead pine needles for the removal of Malachite Green with the aid of ultrasound [74]. The amount and rate of Malachite Green adsorption were markedly increased in the presence of ultrasound. Experimental results indicated that the combination of stirring and ultrasound led to an improvement of the removal of dye. A study to utilize chemically modified maize cob waste with enhanced adsorption properties upon Methyl Orange and arsenic was conducted [75]. Results indicated that the removal of Methyl Orange $(25 \mathrm{mg} / \mathrm{L})$ was less than $50 \%$ by maize cobs modified with phosphorylation, $68 \%$ with 1,4-diaminobutane and $73 \%$ with diethylenetriamine. The removal of Methylene Blue from wastewater using beer brewery waste was performed [76]. Results of surface characterization showed that the pore properties of beer brewery waste were larger than those of its raw materials and it probably provided additional adsorption sites. From the adsorption isotherm, it was found that the adsorption capacity of beer brewery waste was superior and in good agreement with their corresponding physical properties.

The removal of Direct Fast Brown $\mathrm{M}$ by using adsorbent prepared from sewage sludge showed that the optimal conditions for adsorbent were $4 \mathrm{M} \mathrm{ZnCl}_{2}$-immersed sludge pyrolyzed at $550{ }^{\circ} \mathrm{C}$ for 60 minutes [77]. In the same year, a study to remove synthetic dyes using sewage sludge ash (SSA) as adsorbent was attempted [78]. The sewage sludge ash waste was prepared by pyrolysis of municipal wastewater treatment plant sludge and it was used for the removal of Direct Fast Scarlet 4BS and Reactive Brilliant Red K-2BP. The adsorption process was found to be temperature and time dependent and also affected by adsorbent dosage.

The utilization of activated carbon from tyre rubber waste for dye removal was studied [79]. Two types of activated carbon from tyre rubber were prepared, with or without sulfuric acid treatment. The results revealed that some tyre carbons exhibited a more superior performance than a microporous, 
commercial activated carbon. A comparative study on the adsorption of chromium complex dye onto activated carbon and neutral polymeric adsorbent Macronet (MN 200) showed that the effectiveness of MN 200 for dye removal was higher than that of activated carbon [80]. The preparation of $\mathrm{TiO}_{2}$-loaded activated carbon fiber $\left(\mathrm{TiO}_{2} / \mathrm{ACF}\right)$ hybrids through a dip-coating method was conducted [81]. $\mathrm{TiO}_{2} / \mathrm{ACF}$ hybrids were added to a pulsed discharged reactor in order to enhance the decomposition of Methyl Orange.

Preparation of activated carbon from digested sludge of the tannery industry for the adsorption of reactive dye was described [82]. Results showed that the equilibrium data fitted well to Langmuir, Freundlich, and Temkin isotherms and the performance of the activated carbon was good under various experimental conditions. The utilization of activated carbon prepared from Punica granatum for the removal of Acid Blue-29 was studied [83]. Punica granatum was treated with acid and converted into activated carbon. The percent removal of Acid Blue-29 from textile wastewater was reported as $82.35 \%$ at room temperature.

A dynamic isotherm of dye in activated carbon was investigated [84]. The uptake of Reactive Blue $5 \mathrm{G}$ by babassu coconut shell activated carbon was studied and the results obtained showed a favorable dye uptake behavior with maximum adsorption capacity of $12.9 \mathrm{mg} / \mathrm{g}$. The irreversible model fitted the experimental data well when compared to the Langmuir and Freundlich models. The preparation of activated carbon from sunflower oil cake using sulfuric acid activation with different impregnation ratios was attempted [85]. The prepared activated carbon was used for the removal of Methylene Blue from aqueous solutions. Experimental data fitted well in the Langmuir isotherm and pseudo-secondorder kinetic model.

A new approach to decolorize the complex reactive dye bath effluent by a biosorption technique was reported [86]. Corynebacterium glutamicum biomass was decarboxylated and immobilized in polysulfone matrix in order to enhance the decolorization efficiency. Results revealed that the regeneration of this biosorbent can be done using $0.01 \mathrm{M} \mathrm{NaOH}$ up to 25 cycles. Column studies showed that the biosorbent is capable of removing Remazol dye up to $90.6 \%$ over 10 cycles. The development in aerobic biogranulation technology and application in treating textile dyes and other toxic industrial wastewater were studied [87]. The important factors that affect the aerobic granulation were explored through confocal laser scanning microscopic techniques and microscopic observations.

\section{Coagulation/Flocculation}

The feasibility of new tannin-based coagulant-flocculant (Tanfloc) in surface water and textile wastewater treatment at a pilot plant level was tested [88]. The efficacy of water purification was notable in every case and filtration improved the removal of suspended solids, both flocs and turbidity. For the textile industry wastewater, approximately $95 \%$ dye removal was obtained and the results from these pilot studies were similar to or even better than that obtained in batch trials.

Red mud, a by-product of bauxite processing of Bayer process has been investigated for its novel applications in gas cleaning and wastewater treatment [89]. The study revealed promising results of using red mud as a coagulant and adsorbent for both applications as well as a catalyst for some industrial processes. Both leaching and eco-toxicological tests indicate that red mud is not toxic to the environment before and after reuse. 
Decolorization of dye-containing effluent using mineral coagulant produced electrocoagulation was studied [90]. The inorganic coagulants used were labeled as $\mathrm{C} 1$ (produced from electrolysis of $\mathrm{NaOH}$, $7.5 \times 10^{-3} \mathrm{M}$ ), $\mathrm{C} 2$ (from electrolysis of $\mathrm{NaCl}, 10^{-2} \mathrm{M}$ ) and $\mathrm{C} 3$ (from electrolysis of $\mathrm{NaOH}$, $\left.7.5 \times 10^{-3} \mathrm{M}+\mathrm{NaCl}, 10^{-2} \mathrm{M}\right)$. Results showed that the best performance of CI Reactive Red 141 removal was obtained with $\mathrm{C} 2$. The comparison between chemical treatment using $\mathrm{C} 2$ coagulant and direct electrocoagulation revealed that in the first $10 \mathrm{~min}$, the removal efficiency was higher using $\mathrm{C} 2$ as compared to direct electrocoagulation. However, after $60 \mathrm{~min}$ of treatment, direct coagulation showed $100 \%$ removal of CI Reactive Red 141.

\section{Combination of Different Methods}

The application of adsorption filtration technology using reclaimed iron sludge coated sand (RISCS) as filter media for municipal wastewater reuse was studied [91]. Batch experiments were carried out using RISCS and quartz sand (QS) to examine the effect of their dosages on UV254 removal. The removal of UV254 by RISCS was $5.8 \%$ higher than QS filtration. The treatment on wastewater containing Reactive Black 5 (RB 5) using sequencing batch reactor followed by combined aerobic membrane bioreactor/reverse osmosis (AOMBR/RO) was investigated [92]. Results revealed that in the sequencing batch reactor, RB 5 was degraded to aromatic amine which would further mineralize by AOMBR/RO to meet the criteria for reuse.

The photocatalytic and adsorption ability of the prepared $\mathrm{TiO}_{2} /$ adsorbent nanocomposites (TNC) via a facile wet chemical method were studied using Methylene Blue as the model pollutant [93]. Synergistic effects between adsorption and photocatalysis were observed with the assistance of visiblelight irradiation and all TNC achieved higher Methylene Blue removal rates than the adsorption process alone. The integrated sequential photocatalytic oxidation and membrane filtration were used for the treatment of dyestuff effluent [94]. The combined effects of both heterogeneous photocatalytic oxidation and reverse osmosis membrane leads to complete decolorization of the synthetic dyestuff effluent as well as $90 \%$ reduction of initial organic content. In the year 2008, the photocatalytic and combined anaerobic-photocatalytic treatment of textiles dyes was studied [95]. Results demonstrated that photocatalysis was able to remove $90 \%$ of color from crude as well as autoxidized chemically reduced dye solution (biological sequential anaerobic-aerobic treated dye solution).

The combined treatment of ozonation and subsequent biological degradation with a biofilm to reduce the color from textile wastewater was studied by Souza et al. [96]. Results revealed that ozonation of Remazol Black B was effective and the color removal could reach as high as $96 \%$. The subsequent biological treatment was capable of reducing the toxicity of the resulting solution after ozonation. Several biological and chemical coupled treatments for Cibacron Red FN-R azo dye removal were tested [97]. It was reported that the two-stage anaerobic-aerobic biotreatment achieved a higher percentage removal (92-97\%) at different dye concentrations. However, the anaerobically generated colorless solution was found to be more toxic than the initial dye. Hence, a photo-Fenton or ozonation process was used as post-treatment of the anaerobic process for complete dye by-products mineralization.

The non-biodegradable reactive dyes can be treated by the catalytic effects of Fenton's reagent. Fenton's reagent was used to combine both oxidation and coagulation processes [98]. The effects of 
various parameters such as $\mathrm{pH}$, dosage of iron sulfate and hydrogen peroxide, temperature and different concentration of sodium chloride and sodium sulfate were studied. A comparison study on the removal of Acid Green 50 from wastewater by anodic oxidation and electrocoagulation was carried out [99]. Results showed that removal of Acid Green 50 is more economical by using electrocoagulation as compared to anodic oxidation due to lower energy consumption during electrocoagulation. Meanwhile, in another study, the usage of chemical-coagulation followed by sequential batch reactor (SBR) for the decolorization and COD reduction of disperse and reaction dye wastewater was discussed [100]. The color removal efficiency of magnesium chloride aided with lime $\left(\mathrm{MgCl}_{2} / \mathrm{CaO}\right)$ and alum $\left(\mathrm{Al}_{2}\left(\mathrm{SO}_{4}\right)_{3}\right)$ was compared. The utility of $\left(\mathrm{MgCl}_{2} / \mathrm{CaO}\right)$ showed higher color removal as compared to alum.

\section{Other Treatment Methods}

The decolorization of textile dye effluents through current technologies, such as aerobic and anaerobic bacteria, fungi and physical-chemical methods was reviewed [101]. They found that biotechnological applications not only removed color but also completely degraded dyes. Promising results were obtained in enhancing dye removal rate by the addition of mediating compound or by changing process conditions to a higher temperature.

The treatment performance of Acid Orange 7 containing wastewater by using up-flow constructed wetland (UFCW) at different Acid Orange 7 concentrations was investigated [102]. Various concentrations of $\mathrm{AO} 7$, from 50 to $100 \mathrm{mg} / \mathrm{L}$, had an effect on the performance in biodegradation of organic matter and nitrification in the non-aerated wetland reactor as well as denitrification and decolorization in the aerated wetland reactor. For the removal of organic matter, $\mathrm{NH}_{4}-\mathrm{N}$ and aromatic amines, the aerated wetland reactor outperformed the non-aerated one. The usage of constructed wetland $(\mathrm{CW})$ for dye-rich textile wastewater treatment was carried out under a series of dynamic experiments [103]. The CW model was packed with gravel, sand and zeolite tuff. Results indicated that the CW model could reduce color by up to $70 \%$.

The usage of the high thermal energy of high-temperature printing and dyeing wastewater to activate persulfate (PS) for dye treatment was carried out [104]. Acid Orange 7 degradation was enhanced by increasing the temperature or PS concentration. The optimum $\mathrm{pH}$ for degradation of Acid Orange 7 was found to be $\mathrm{pH}$ 7. The decolorization of Acid Orange 7 by a non-thermal plasma technique (i.e., the gas-liquid gliding arc discharge, which was generated between at least two metal electrodes with AC high voltage) was studied [105]. Results showed that the concentration of Acid Orange 7 decreases exponentially to reach 58.9, 77.4, 89.1, 95.1 and 99\% in 25, 50, 75, 100 and 125 min, respectively. The $\ln \left(\mathrm{C}_{\mathrm{t}} / \mathrm{C}_{\mathrm{o}}\right)$ varied linearly with treatment time, which indicates that the decolorization reaction followed the pseudo-first-order kinetic model.

Enhanced biodegradation of Reactive Violet 5R manufacturing wastewater using a down flow fixed film bioreactor (DFFR) was performed [106]. Charcoal was used as a support material in DFFR. In less than eight hours of contact time, more than $88 \%$ COD reduction, 95\% degradation of Reactive Violet 5R and $99 \%$ of copper remediation was observed under both batch and continuous operation of DFFR. The biodegradation rate increased more than three-fold with an additional $0.25 \%$ of peptone. 
The feasibility of using foam separation for color removal from direct dye-containing wastewater was studied [107]. By using cetyl trimethyl ammonium bromide as a collector for foam separation, this provided good foaming quality and effective color removal from textile wastewater. Under the optimal conditions, a removal efficiency of $88.9 \%$ was achieved and the residual dye content met the discharge standard published by the Ministry of Environmental Protection of the People's Republic of China.

Two operational strategies, the decentralized model and innovative integrated model, in industrial wastewater treatment plants (IWTPs) were studied [108]. Results revealed that the integrated model has improved IWTP performance although it had a higher operational cost.

The usage of direct current (DC) diaphragm discharge for the decolorization of Direct Red 79 was attempted [109]. A high removal rate was observed after 40 minutes. This method can lead to a change in solution properties such as $\mathrm{pH}$ of the solution and solution conductivity.

A comparison on Acid Red 119 dye removal by using two different types of waterworks sludge, ferric chloride sludge (FCS) and polyaluminium chloride sludge (PACS), was carried out [110]. These waterwork sludges acted as coagulant to remove Acid Red 119 under a series of batch experiments. Results indicated that FCS was more effective than PACS for the Acid Red removal due to its higher maximum adsorption capacity.

The feasibility of using wasted basic oxygen furnace (BOF) slag in the removal of diazo dye C.I. Acid Black 24 revealed that BOF slag efficiently removed Acid Black 24 by up to $99.7 \%$ [111]. The color removal efficiency was dependent on slag dose and initial dye concentration.

Thermal-pressure-mediated hydrolysis of Reactive Blue 19 was studied [112]. A linear relationship between hydrolysis rate of Reactive Blue 19 and increasing temperature and pressure was reported. Acidic conditions were more conducive to increase the hydrolysis rate.

The possibility of using sugarcane extract as an alternative for hydrose, a reducing agent that produced large amounts of toxic by-products in vat dyeing, was explored [113]. Sugarcane extract is eco-friendly as compared to others reduction method likes electrochemical and ultrasonic energy.

The electrochemical degradation of Alizarin Red S using an activated carbon fiber (ACF) felt as an anode was investigated [114]. Results indicated that increasing current density would increase dye removal efficiency. It was found that the larger surface area of the ACF anode $\left(1682 \mathrm{~m}^{2} / \mathrm{g}\right)$ could ensure more effective electrochemical degradation of dye (83.9\%).

Experiments on the decolorization and decomposition of reactive and disperse dyes using electron beam technology were carried out [115]. It was found that the dose of irradiation and initial concentration of pollutants affects the removal of color and they are dependent on each other. At an irradiation dose of $108 \mathrm{kGy}$, the color removal was in the range of $87 \%-96 \%$.

One and two-stage anaerobic treatment systems were used to decolorize synthetic dye solution containing Congo Red and real textile wastewater [116]. The removal of Congo Red was highly effective in both treatment systems. However, low decolorization efficiency was observed with real textile wastewater and this is most likely due to the presence of dyes not susceptible to reductive decolorization under the experimental conditions.

\section{Acknowledgement}

The financial support by the International Foundation of Science, Stockholm, Sweden, and the Organisation for the Prohibition of Chemical Weapons, The Hague, The Netherlands via grant no. 
W/4368-1 and research facilities from Universiti Tunku Abdul Rahman (UTAR) are gratefully acknowledged.

\section{References}

1. Ng, T.W.; Cai, Q.; Wong, C.-K.; Chow, A.T.; Wong, P.-K. Simultaneous chromate reduction and azo dye decolorization by Brevibacterium casei: Azo dye as electron donor for chromate reduction. J. Hazard. Mater. 2010, 182, 792-800.

2. Ghasemi, F.; Tabandeh, F.; Bambai, B. Decolorization of different azo dyes by phanerochaete chrysosporium RP78 under optimal condition. Int. J. Environ. Sci. Technol. 2010, 7, 457-464.

3. Pakshirajan, K.; Singh, S. Decolorization of synthetic wastewater containing azo dyes in a batch-operated rotating biological contactor reactor with the immobilized fungus phanerochaete chrysosporium. Ind. Eng. Chem. Res. 2010, 49, 7484-7487.

4. Andleeb, S.; Atiq, N.; Ali, M.I.; Razi-Ul-Hussnain, R.; Shafique, M.; Ahamad, B.; Ghumro, P.B.; Ahmad, S. Biological treatment of textile effluent in stirred tank bioreactor. Int. J. Agriculture Bio. 2010, 12, 256-260.

5. Kilic, N.K.; Duygu, E.; Donmez, G. Triacontanol hormone stimulates population, growth and Brilliant Blue R dye removal by common duckweed from culture media. J. Hazard. Mater. 2010, $182,525-530$.

6. Karacakaya, P.; Kilic, N.K.; Duygua, E.; Donmez, G. Stimulation of reactive dye removal by cyanobacteria in media containing triacontanol hormone. J. Hazard. Mater. 2009, 172, 1635-1639.

7. Ozer, A.; Turabik, M.; Akkaya, G. Biosorption of acid dyes by brown alga dictyota dichotoma: Equilibrium, kinetic and thermodynamic studies. Fresenius Environ. Bull. 2009, 18, 1798-1808.

8. Nilratnisakorn, S.; Thiravetyan, P.; Nakbanpote, W. A constructed wetland model for synthetic reactive dye wastewater treatment by narrow-leaved cattails (Typha angustifolia Linn). Water Sci. Technol. 2009, 60, 1565-1574.

9. Prabakaran, G.; Pugalvendhan, R.; Jayaseelan, M. Studies on textile dye degradation by aspergillus niger from dye contaminated soil. Pollut. Res. 2009, 28, 555-560.

10. Won, S.W.; Vijayaraghavan, K.; Mao, J.; Kim, S.; Yun, Y.-S. Reinforcement of carboxyl groups in the surface of Corynebacterium glutamicum biomass for effective removal of basic dyes. Bioresour. Technol. 2009, 100, 6301-6306.

11. Nehra, K.; Anju, M.; Malik, K. Isolation and optimization of conditions for maximum decolorization by textile-dye decolorizing bacteria. Pollut. Res. 2008, 27, 257-264.

12. Bafana, A.; Krishnamurthi, K.; Devi, S.S.; Chakrabarti, T. Biological decolorization of C.I. Direct Black 38 by E. gallinarum. J. Hazard. Mater. 2008, 157, 187-193.

13. Bafana, A.; Chakrabarti, T.; Krishnamurthi, K.; Devi, S.S. Biodiversity and dye decolorization ability of an acclimatized textile sludge. Bioresour. Technol. 2008, 99, 5094-5098.

14. Raghukumar, C.; D'Souza Ticlo, D.; Verma, A.K. Treatment of colored effluents with lignin-degrading enzymes: An emerging role of marine-derived fungi. Crit. Rev. Microbiol. 2008, 34, 189-206. 
15. Cetin, D.; Donmez, S.; Donmez, G. The treatment of textile wastewater including chromium(VI) and reactive dye by sulfate-reducing bacterial enrichment. J. Environ. Manage. 2008, 88, 76-82.

16. Khalid, A.; Arshad, M.; Crowley, D.E. Decolorization of azo dyes by Shewanella sp. under saline conditions. Appl. Microbiol. Biotechnol. 2008, 79, 1053-1059.

17. Dawkar, V.V.; Jadhav, U.U.; Jadhav, S.U.; Govindwar, S.P. Biodegradation of disperse textile dye brown 3REL by newly isolated Bacillus sp. VUS. J. Appl. Microbiol. 2008, 105, 14-24.

18. Valdes, H.; Godoy, H.P.; Zaror, C.A. Heterogeneous catalytic ozonation of cationic dyes using volcanic sand. J. Int. Assoc. Water Pollut. Res. 2010, 61, 2973-2978.

19. Xiu, F-R.; Zhang F-S. Preparation of nano- $\mathrm{Cu}_{2} \mathrm{O} / \mathrm{TiO}_{2}$ photocatalyst from waste printed circuit boards by electrokinetic process. J. Hazard. Mater. 2009, 172, 1458-1463.

20. Khataee, A.R.; Fathinia, M.; Aber, S.; Zarei, M. Optimization of photocatalytic treatment of dye solution on supported $\mathrm{TiO}_{2}$ nanoparticles by central composite design: Intermediates Identification. J. Hazard. Mater. 2010, 181, 886-897.

21. Damodar, R.A.; You, S-.J.; Chou, H.-H. Study of self cleaning, antibacterial and photocatalytic properties of $\mathrm{TiO}_{2}$ entrapped PVDF membrane. J. Hazard. Mater. 2009, 172, 1321-1328.

22. Yun, J.; Jijn, D.; Lee, Y-S.; Kim, H-I. Photocatalytic treatment of acidic wastewater by electrospun composite nanofibers of $\mathrm{pH}$-sensitive hydrogel and $\mathrm{TiO}_{2}$. Mater. Lett. 2010, 64, 2431-2434.

23. Lin, Y.-C.; Lee, H.-S. Effects of $\mathrm{TiO}_{2}$ coating dosage and operational parameters on a $\mathrm{TiO}_{2} / \mathrm{Ag}$ photocatalysis system for decolorizing Procion red MX-5B. J. Hazard. Mater. 2010, 179, 462-470.

24. Wu, Z.-C.; Zhang, Y.; Tao, T.-X.; Zhang, L.; Fong, H. Silver nanoparticles on amidoxime fibers for photo-catalytic degradation of organic dyes in waste water. Appl. Surf. Sci. 2010, 257, 1092-1097.

25. Sun, J.-H.; Dong, S.-Y.; Wang, Y.-K.; Sun, S.-P. Preparation and photocatalytic property of a novel dumbbell shape $\mathrm{ZnO}$ microcrystal photocatalyst. J. Hazard. Mater. 2009, 172, 1520-1526.

26. Yu, F.; Shi, L. Catalytic oxidation and spectroscopic analysis of stimulated wastewater containing Acid Chrome Blue K by using chlorine dioxide as oxidant. Water Sci. Technol. 2010, 61, 1931-1940.

27. Valero, D.; Ortiz, J.M.; Exposito, E.; Montiel, V.; Aldaz, A. Electrochemical wastewater treatment directly powered by photovoltaic panels: Electrooxidation of a dye-containing wastewater. Environ. Sci. Technol. 2010, 44, 5182-5187.

28. Maljaei, A.; Arami, M.; Mahmoodi, N.M. Decolorization and aromatic ring degradation of colored textile wastewater using indirect electrochemical oxidation method. Desalination 2009, 249, 1074-1078.

29. Lodha, S.; Jain, A.; Punjabi, P.B. A novel route for waste water treatment: Photocatalytic degradation of Rhodamine B. Arabian J. Chem. 2010, in press.

30. Lv, J.-X.; Xie, G.-H.; Yue, Q.-L.; Zhang, L.; Li, J.-M.; Cui, Y. $\mathrm{H}_{2} \mathrm{O}_{2}$-assisted photolysis of reactive BES Golden Yellow simulated wastewater. Water Sci. Technol. 2009, 60, 2329-2336.

31. Mounteer, A.H.; Leite, T.A.; Lopes, A.C.; Medeiros, R.C. Removing textile mill effluent recalcitrant COD and toxicity using the $\mathrm{H}_{2} \mathrm{O}_{2} / \mathrm{UV}$ system. Water Sci. Technol. 2009, 60, 1895-1902. 
32. Bauman, M.; Poberznik, M.; Lobnik, A. Textile wastewater cleaning with $\mathrm{O}_{3}$ and $\mathrm{H}_{2} \mathrm{O}_{2} / \mathrm{O}_{3}$ process. Tekstilec. 2009, 52, 284-305.

33. Mahamuni, N.N.; Adewuyi, Y.G. Advanced oxidation processes (AOPs) involving ultrasound for waste water treatment: A review with emphasis on cost estimation. Ultrason. Sonochem. 2010, 17, 990-1003.

34. Zhang, H.; Fu, H.; Zhang, D. Degradation of C.I. Acid Orange 7 by ultrasound enhanced heterogeneous Fenton-like process. J. Hazard. Mater. 2009, 172, 654-660.

35. Hsieh, L.-L.; Kang, H.-J.; Shyu, H.-L.; Chang, C.-Y. Optimal degradation of dye wastewater by ultrasound/Fenton method in the presence of nanoscale iron. Water Sci. Technol. 2009, 60, 1295-1301.

36. Wang, Y.; Zhao, D.; Ma, W.; Chen, C.; Zhao, J. Enhanced sonocatalytic degradation of azo dyes by $\mathrm{Au} / \mathrm{TiO}_{2}$. Environ. Sci. Technol. 2008, 42, 6173-6178.

37. Wang, J.; Jiang, Z.; Zhang, Z.; Xie, Y.; Wang, X.; Xing, Z.; Xu, R.; Zhang, X. Sonocatalytic degradation of Acid Red B and Rhodamine B catalyzed by nano-sized ZnO powder under ultrasonic irradiation. Ultrason. Sonochem. 2008, 15, 768-774.

38. Liu, Z.-H.; Liu, R.-L.; Mu, T.-M.; Zuo, Z.-H.; Tao, C.-Y. Degradation of Methyl Orange solution by microwave-assisted catalysis of $\mathrm{H}_{2} \mathrm{O}_{2}$ with chromium residue. Spec. Spectr. Anal. 2008, 28, 1900-1904.

39. Cristovao, R.O.; Tavares, A.P.M.; Loureiro, J.M.; Boaventura, R.A.R.; Macedo, E.A. Treatment of kinetic modeling of a simulated dye house effluent by enzymatic catalysis. Bioresour. Technol. 2009, 100, 6236-6242.

40. Xu, Y.L.; Zhong, D.J.; Jia, J.P.; Chen, S.; Li, K. Enhanced dye wastewater degradation efficiency using a flowing aqueous film photoelectrocatalytic reactor. J. Environ. Sci. Health A 2008, 43, 1215-1222.

41. Ren, X.; Wang, T.; Zhou, C.; Du, S.; Luan, Z.; Wang, J.; Hou, D. Treatment of dye aqueous solution using a novel aromatic polyamide asymmetric nanofiltration membrane. Fresenius Environ. Bull. 2010, 19, 1441-1446.

42. Han, R.; Zhang, S.; Xing, D.; Jian, X. Desalination of dye utilizing copoly(phthalazinone biphenyl ether sulfone) ultrafiltration membrane with low molecular weight cut-off. J. Membrane Sci. 2010, 358, 1-6.

43. Rekha, R.; Chauhan, P.; Gangopadhyay, U.K. Zero effluent process by using membrane type solute separation systems for wet process house. Asian Text. J. 2009, 18, 65-69.

44. Altenbaher, B.; Turk, S.S. Treatment of textile processing wastewater with membrane filtrations. Tekstil. 2009, 58, 367-383.

45. Salehi, R.; Arami, M.; Mahmoodi, N.M.; Bahrami, H.; Khorramfar, S. Novel biocompatible composite (Chitosan-zinc oxide nanoparticle): Preparation, characterization and dye adsorption properties. Colloids Surf. 2010, B80, 86-93.

46. Wong, Y.C.; Szeto, Y.S.; Cheung, W.H.; McKay, G. Sorption kinetics for the removal of dyes from effluents onto chitosan. J. Appl. Polym. Sci. 2008, 109, 2232-2242.

47. Rosa, S.; Laranjeira, M.C.M.; Riela, H.G.; Favere, V.T. Cross-linked quaternary chitosan as an adsorbent removal of the reactive dye from aqueous solutions. J. Hazard. Mater. 2008, 155, 253-260. 
48. Jalil, A.A.; Triwahyono, S.; Adam, S.H.; Rahim, N.D.; Aziz, M.A.A.; Hairom, N.H.H.; Razali, N.A.M.; Mohamadiah, M.K.A. Adsorption of Methyl Orange from aqueous solution onto calcinated Lapindo volcanic mud. J. Hazard. Mater. 2010, 181, 755-762.

49. Asuha, S.; Zhou, X.G.; Zhao, S. Adsorption of Methyl Orange and $\mathrm{Cr}(\mathrm{VI})$ on mesoporous $\mathrm{TiO}_{2}$ prepared by hydrothermal method. J. Hazard. Mater. 2010, 181, 204-210.

50. Haque, E.; Lee, J.E.; Jang, I.T.; Hwang, Y.K.; Chang, J.-S.; Jegal, J.; Jhung, S.H. Adsorptive removal of Methyl Orange from aqueous solution with metal-organic frameworks, porous chromium-benzenecarboxylates. J. Hazard. Mater. 2010, 181, 535-542.

51. Chakrabarti, S.; Dutta, B.K.; Apak, R. Active manganese oxide: A novel adsorbent for treatment of wastewater containing azo dye. Water Sci. Technol. 2009, 60, 3017-3024.

52. Kannan, C.; Sundaram, T.; Palvannan, T. Environmentally stale adsorbent of tetrahedral silica and non-tetrahedral alumina for removal and recovery of malachite green dye from aqueous solution. J. Hazard. Mater. 2008, 157, 137-145.

53. Guan, J.F.; Liu, J.; Hu, X.F.; Liu, Z.W.; Lin, H. Application on dyeing wastewater treatment by tourmaline. In Proceedings of the 3rd International Conference on Bioinformatics and Biomedical Engineering; iCBBE: Beijing, China, 11-13 June 2009.

54. Liu, Q.; Wang, L.; Xiao, A.; Gao, J.; Ding, W.; Yu, H.; Huo, J.; Ericson, M. Templated preparation of porous magnetic microspheres and their application in removal of cationic dyes from wastewater. J. Hazard. Mater. 2010, 181, 586-593.

55. Iram, M.; Guo, C.; Guan, Y.; Ishfaq, A.; Liu, H. Adsorption and magnetic removal of neutral red dye from aqueous solution using $\mathrm{Fe}_{3} \mathrm{O}_{4}$ hollow nanospheres. J. Hazard. Mater. 2010, 181, 1039-1050.

56. Srinivasan, A.; Viraraghavan, T. Decolourization of dye wastewaters by biosorbents: A review. J. Environ. Manage. 2010, 91, 1915-1929.

57. Rafatullah, M.; Sulaiman, O.; Hashim, R.; Ahmad, A. Adsorption of Methylene Blue on low-cost adsorbents: A review. J. Hazard. Mater. 2010, 177, 70-80.

58. Sun, D.; Zhang, X.; Wu, Y.; Liu, X. Adsorption of anionic dyes from aqueous solution on fly ash. J. Hazard. Mater. 2010, 181, 335-342.

59. Smelcerovic, M.; Dordevic, D.; Novakovic, M.; Mizdrakovic, M. Decolorization of a textile vat dye by adsorption on waste ash. J. Serb. Chem. Soc. 2010, 75, 855-872.

60. Saad, S.A.; Isa, K.Md.; Bahari, R. Chemically modified sugarcane bagasse as a potentially low-cost biosorbent for dye removal. Desalination 2010, 1-2, 123-128.

61. Ong, S.T.; Khoo, E.C.; Hii, S.L.; Ha, S.T. Utilization of sugarcane bagasse for removal of basic dyes from aqueous environment in single and binary systems. Desalination Water Treat. J. 2010, 20, 86-95.

62. Lee, C.K.; Ong, S.T.; Zainal, Z. Ethylenediamine modified rice hull as a sorbent for the removal of Basic Blue 3 and Reactive Orange 16. Int. J. Environ. Pollut. 2008, 34, 246-260.

63. Ong, S.T.; Tay, E.H.; Ha, S.T.; Lee, W.N.; Keng, P.S. Equilibrium and continuous flow studies on the sorption of Congo Red using ethylenediamine modified rice hulls, Int. J. Phys. Sci. 2009, 4, 683-690. 
64. Ong, S.T.; Lee, W.N.; Keng, P.S.; Lee, S.L.; Hung, Y.T.; Ha, S.T. Equilibrium studies and kinetics mechanism for the removal of basic and reactive dyes in both single and binary systems using EDTA modified rice husk, Int. J. Phys. Sci. 2010, 5, 582-595.

65. Mital, A.; Jain, R.; Mittal, J.; Shrivastava, M. Adsorptive removal of hazardous dye Quinoline Yellow from wastewater using coconut-husk as potential adsorbent. Fresenius Environ. Bull. 2010, 19, 1171-1179.

66. Oliveira, L.S.; Franca, A.S.; Alves, T.M.; Rocha, S.D.F. Evaluation of untreated coffee husks as potential biosorbents for treatment of dye contaminated waters. J. Hazard Mater. 2008, 155, 507-512.

67. Saeed, A.; Sharif, M.; Iqbal, M. Application potential of grapefruit peel as dye sorbent: Kinetics, equilibrium, and mechanism of crystal violet adsorption. J. Hazard. Mater. 2010, 179, 564-572.

68. Deniz, F.; Saygideger, S.D. Equilibrium, kineticm and thermodynamic studies of Acid Orange 52 dye biosorption by Paulownia tomentosa Steud. leaf powder as a low-cost natural biosorbent. Bioresour. Technol. 2010, 101, 5137-5143.

69. Nagda, G.K.; Ghole, V.S. Biosorption of Congo Red by hydrogen peroxide treated tendu waste. Iranian J. Environ. Health Sci. Eng. 2009, 6, 195-200.

70. Parab, H.; Sudersanan, M.; Shenoy, N.; Pathare, T.; Vaze, B. Use of Agro-Industrial Wastes for the Removal of Basic Dyes from Aqueous Solutions. In Proceedings of the 2nd International Conference and Exhibition on Water in the Environment, Stellenbosch, South Africa, 2-4 March 2009; Volume 37, pp. 963-969.

71. Mizdrakovic, M.; Dordevic, D.; Novakovic, M.; Smelcerovic, M. The removal of base dyes from wastewater model by adsorption at waste ashes. Tekstil. 2009, 58, 591-599.

72. Mittal, A.; Mittal, J.; Malviya, A.; Gupta, V.K. Adsorptive removal of hazardous anionic dye 'Congo Red' from wastewater using waste materials and recovery by desorption. J. Colloid. Interf. Sci. 2009, 340, 16-26.

73. Song, L.; Chen, J.; Gao, J.; He, B.; Wei, M.; Wang, Y. Adsorbent for waste water treatment made from waste drilling fluids. Drill. Fluid Complet. Fluid 2009, 26, 86.

74. Hamdaoui, O.; Chiha, M.; Naffrechoux, E. Ultrasound-assisted removal of malachite green from aqueous solution by dead pine needles. Ultrason. Sonochem. 2008, 15, 799-807.

75. Elizalde-Gonzalez, M.P.; Mattusch, J.; Wennrich, R. Chemically modified maize cobs waste with enhanced adsorption properties upon Methyl Orange and arsenic. Bioresour. Technol. 2008, 99, 5134-5139.

76. Tsai, W.-T.; Hsu, H.-C.; Su, T.-Y.; Lin, K.-Y.; Lin, C.-M. Removal of basic dye (Methylene Blue) from wastewaters utilizing beer brewery waste. J. Hazard. Mater. 2008, 154, 73-78.

77. Chen, C.Y.; Zhuang, Y.Y. Adsorbent derived from sewage sludge and its application in dye wastewater treatment. In Proceedings of the 3rd International Conference on Bioinformatics and Biomedical Engineering; iCBBE: Beijing, China, 11-13 June 2009.

78. Zhang, L.; Chen, J.; Liu, L.; An, F.; Li, D. Decolorization of synthetic dye wastewater with sewage sludge ash used as adsorbent. Acta Sci. Circumst. 2009, 29, 2510-2518.

79. Mui, E.L.K.; Cheung, W.H.; Valix, M.; Mckay, G. Dye adsorption onto activated carbons from tyre rubber waste using surface coverage analysis. J. Colloid Interf. Sci. 2010, 347, 290-300. 
80. Kauspediene, D.; Kazlauskiene, E.; Gefeniene, A.; Binkiene, R. Comparison of the efficiency of activated carbon and neutral polymeric adsorbent in removal of chromium complex dye from aqueous solutions. J. Hazard. Mater. 2010, 179, 933-939.

81. Zhang, Y.; Deng, S.; Sun, B.; Xiao, H.; Li, L.; Yang, G.; Hui, Q.; Zheng, J. Preparation of $\mathrm{TiO}_{2}$-loaded activated carbon fiber hybrids and application in a pulsed discharge reactor for decomposition of Methyl Orange. J. Colloid Interf. Sci. 2010, 347, 260-266.

82. Govindasami, S.; Phani Kumar, B.R.; Balamurali Krishna, C.; Mayildurai, R. Equilibrium and isotherm studies of sludge based activated carbon. Ecol. Environ. Conserv. 2009, 15, 817-824.

83. Jalajaa, P.; Manjuladevi, M.; Saravanan, S.V. Removal of acid dye from textile waste water by adsorption using activated carbon prepared from Punica Granatum (Pomegranate) rind. Pollut. Res. 2009, 28, 287-290.

84. Matta, G.K.L.; Barros, M.A.S.D.; Lambrecht, R.; da Silva, E.A.; da Motta Lima, O.C. Dynamic isotherms of dye in activated carbon. Mater. Res. 2008, 11, 365-369.

85. Karagoz, S.; Tay, T.; Ucar, S.; Erdem, M. Activated carbons from waste biomass by sulfuric acid activation and their use on Methylene Blue adsorption. Bioresour. Technol. 2008, 99, 6214-6222.

86. Vijayaraghavan, K.; Lee, M.W.; Yun, Y.-S. A new approach to study the decolorization of complex reactive dye bath effluent by biosorption technique. Bioresour. Technol. 2008, 99, 5778-5785.

87. Adav, S.S.; Lee, D.-J.; Show, K.-Y.; Tay, J.-H. Aerobic granular sludge: Recent advances. Biotechnol. Adv.s 2008, 26, 411-423.

88. Sanchez-Martin, J.; Beltran-Heredia, J.; Solera-Hernandez, C. Surface water and wastewater treatment using a new tannin-based coagulant, Pilot plant trials. J. Environ. Manage. 2010, 91, 2051-2058.

89. Wang, S.; Ang, H.M.; Tade, M.O. Novel applications of red mud as coagulant, adsorbent and catalyst for environmentally benign processes. Chemosphere 2008, 72, 1621-1635.

90. Zidane, F.; Drogui, P.; Lekhlif, B.; Bensaid, J.; Blais, J.-F.; Belcadi, S.; Kacemi, K.E. Decolorization of dye-containing effluent using mineral coagulants produced by electrocoagualtion. J. Hazard. Mater. 2008, 155, 153-163.

91. Lu, J.; Sun, L.; Li,Y.; Jia, R.; Yi, X. Adsorption filtration technology using reclaimed iron sludge coated sand filter media for municipal wastewater reuse. In Proceedings of the 4th International Conference on Bioinformatics and Biomedical Engineering; iCBBE: Chengdu, China, 18-20 June 2010.

92. You, S.-J.; Teng, J.-Y. Performance and dye-degrading bacteria isolation of a hybrid membrane process. J. Hazard. Mater. 2009, 172, 172-179.

93. Zhang, W.; Zuo, L.; Wang, L. Visible-light assisted Methylene Blue (MB) removal by novel $\mathrm{TiO}_{2}$ /adsorbent nanocomposites. Water Sci. Technol. 2010, 61, 2863-2871.

94. Berberidou, C.; Avlonitis, S.; Poulios, I. Dyestuff effluent treatment by integrated sequential photocatalytic oxidation and membrane filtration. Desalination 2009, 249, 1099-1106.

95. Harrelkas, F.; Paulo, A.; Alves, M.M.; El Khadir, L.; Zahraa, O.; Pons, M.N.; van der Zee, F.P. Photocatalytic and combined anaerobic-photocatalytic treatment of textile dyes. Chemosphere 2008, 72, 1816-1822. 
96. de Souza, S.M.D.A.G.U.; Bonilla, K.A.S.; de Souza, A.A.U. Removal of COD and color from hydrolyzed textile azo dye by combined ozonation and biological treatment. J. Hazard. Mater. 2010, 179, 35-42.

97. Garcia-Montano, J.; Domenech, X.; Garcia-Hortal, J.A.; Torrades, F.; Peral, J. The testing of several biological and chemical coupled treatments for Cibacron Red FN-R azo dye removal. J. Hazard. Mater. 2008, 154, 484-490.

98. Emami, F.; Tehrani-Bagha, A.R.; Gharanjig, K.; Menger, F.M. Kinetic study of the factors controlling Fenton-promoted destruction of a non-biodegradable dye. Desalination 2010, 257, 124-128.

99. El-Ashtoukhy, E.-S.Z.; Amin, N.K. Removal of acid green dye 50 from wastewater by anodic oxidation and electrocoagulation-A comparative study. J. Hazard. Mater. 2010, 179, 113-119.

100. El-Gohary, F.; Tawfik, A. Decolorization and COD reduction of disperse and reactive dyes wastewater using chemical-coagulation followed by sequential batch reactor. Desalination 2009, 249, 1159-1164.

101. Ramachandran, T.; Ganesan, P.; Hariharan, S. Decolourization of textile effluents-An overview. J. Inst. Engineers (India) TX 2009, 90, 20-25.

102. Ong, S.-A.; Uchiyama, K.; Inadama, D.; Ishida, Y.; Yamagiwa, K. Treatment of azo dye Acid Orange 7 containing wastewater using up-flow constructed wetland with and without supplementary aeration. Bioresour. Technol. 2010, 101, 9049-9057.

103. Bulc, T.G.; Ojstrsek, A. The use of constructed wetland for dye-rich textile wastewater treatment. J. Hazard. Mater. 2008, 155, 76-82.

104. Wang, P.; Yang, S.; Shan, L.; Yang, X.; Zhang, W.; Shao, X.; Niu, R. Waste heat-activated persulfate degradation of dye wastewater. In Proceedings of the 4th International Conference on Bioinformatics and Biomedical Engineering; iCBBE: Chengdu, China, 18-20 June 2010.

105. Du, C.; Shi, T.; Sun, Y.; Zhuang, X. Decolorization of Acid Orange 7 solution by gas-liquid gliding arc discharge plasma. J. Hazard. Mater. 2008, 154, 1192-1197.

106. Sheth, N.; Dave, S. Enhanced biodegradation of Reactive Violet 5R manufacturing wastewater uing down flow fixed film bioreactor. Bioresour. Technol. 2010, 101, 8627-8631.

107. Lu, K.; Zhang, X.-L.; Zhao, Y.-L.; Wu, Z.-L. Removal of color from textile dyeing wastewater by foam separation. J. Hazard. Mater. 2010, 182, 928-932.

108. Yuan, Z.; Jiang, W.; Bi, J. Cost-effectiveness of two operational models at industrial wastewater treatment plants in China: A case study in Shengze town, Suzhou City. J. Environ. Manage. 2010, 91, 2038-2044.

109. Kozakova, Z.; Nejezchle, M.; Krcma, F.; Halamova, I.; Caslavsky, J.; Dolinova, J. Removal of organic dye Direct Red 79 from water solutions by DC diaphragm discharge: Analysis of decomposition products. Desalination 2010, 258, 93-99.

110. Sadri Moghaddam, S.; Alavi Moghaddam, M.R.; Arami, M. A comparison study on Acid Red 119 dye removal using two different types of waterworks sludge. Water Sci. Technol. 2010, 61, 1673-1681.

111. Chang, M.-C.; Shu, H.-Y.; Chang, C.-C.; Chen, W.-H. Using wasted basic oxygen furnace (BOF) slag for decolorization of diazo dye Acid Black 24 wastewater. Fresenius Environ. Bull. 2010, $19,1118-1124$. 
112. Siddique, M.; Farooq, R.; Khalid, A.; Farooq, A.; Mahmood, Q.; Farooq, U.; Raja, I.A.; Shaukat, S.F. Thermal-pressure-mediated hydrolysis of Reactive Blue 19 dye. J. Hazard. Mater. 2009, 172, 1007-1012.

113. Gnanavel, P.; Kumar, P.M.; Ananthakrishnan, T. Effect of sugarcane extract in vat dyeing. Man-Made Textiles in India 2009, 52, 432-433.

114. Yi, F.; Chen, S.; Yuan, C. Effect of activated carbon fiber anode structure and electrolysis conditions on electrochemical degradation of dye wastewater. J. Hazard. Mater. 2008, 157, 79-87.

115. Ting, T.-M.; Jamaludin, N. Decolorization and decomposition of organic pollutants for reactive and disperse dyes using electron beam technology: Effect of concentration of pollutants and irradiation dose. Chemosphere 2008, 73, 76-80.

116. Firmino, P.I.M.; da Silva, M.E.R.; Cervantes, F.J.; dos Santos, A.B. Color removal of dyes from synthetic and real textile wastewaters in one- and two-stage anaerobic systems. Bioresour. Technol. 2010, 101, 7773-7779.

(C) 2011 by the authors; licensee MDPI, Basel, Switzerland. This article is an open access article distributed under the terms and conditions of the Creative Commons Attribution license (http://creativecommons.org/licenses/by/3.0/). 